\title{
An Application of Learning Logs for Measuring Mathematics Course Lengths in Primary Education
}

\author{
Yasin Gökbulut ${ }^{1, *}$, Zeynep Eren ${ }^{2}$ \\ ${ }^{1}$ Education Faculty, University of Gaziosmanpaşa, Tokat, Turkey \\ ${ }^{2}$ Junior Technical College, University of Gaziosmanpaşa, Tokat, Turkey
}

Copyright $\odot 2018$ by authors, all rights reserved. Authors agree that this article remains permanently open access under the terms of the Creative Commons Attribution License 4.0 International License

\begin{abstract}
In this research, the effect of using learning logs in the learning of length subjects of primary school fourth graders was investigated. The study group was composed of 35 state primary school students, determined by an easily accessible sampling method in the province of Tokat in 2014-2015 academic years. The method of the study is an experimental model with pre-test and post-test control group. In this study, "Learning Logs" which was developed by the researchers for the 4th grade mathematics course length measuring understanding test (LMUT) as the pre-test and final test data collection tool and learning logs prepared to create the effect on the pre-test-post test data were used. LMUT was prepared as consisting of fifteen questions with four multiple choices after meticulously preparation period with literature review. The experimental study performed at eight-week period. Data collected from pre-test and post-test were analyzed by covariance analysis and t-test. As a result of this study, it was seen that learning logs effected learning positively and the academic success of the course was positively boosted. It was also found that learning journals significantly increased the success of girl students compared to boy students.
\end{abstract}

Keywords Learning Logs, Reflective Thinking, Measuring Length

\section{Introduction}

Mathematics is generally seen as a lesson learned and used only in school. However, a significant number of mathematical subjects were born and advanced by the need to solve the problems of people [24]. People used this information in their daily lives. With the development of technology use in the world so with Turkey, there is an increased interest in mathematics has occurred. The place of mathematics in human life seems to be effective even in the production of technological products that are increasing day by day and making our life easier [13]. Because of these reasons, mathematics lesson and the success of this lesson is very important. However, student's negative viewpoints on mathematics lesson and negative prejudices make it difficult to learn this lesson. The task of educators in mathematics teaching is to make children love mathematics. Mathematics is generally made up of abstract subjects. Children in the age of primary school are in the process of concrete transactions, so their math's and their conception become difficult. Educators are required to teach mathematics by integrating them into more concrete and daily life. However, the number of teachers teaching in these terms is not sufficient in Turkey [14]. We have expected with this study that the educators will learn a different way about mathematics teaching and provision mathematics instruction to the students more easily.

There are many international mathematics education assessment exams. The most prominent of these is the PISA (Program for International Student Assessment). PISA exam measures the knowledge and abilities of children aged fifteen years. Assessments have done about reading, mathematics, science and problem solving skills. The examination measures how students can demonstrate what they know outside of school and in different situations and conditions. The aim of the exams conducted by the organization for economic co-operation and development (OECD) is to promote mathematics and science education in international standards and to create high-welfare communities that can plan their own problems and plan their economies. Significant statistics have been obtained with the exams made over the years. These statistical results have been observed that Turkey has a low overall success in mathematics performance. PISA exam has been carried out in Turkey since 2003 with an interval of three years. The highest success rating of Turkey out of 65 countries was 42; the lowest success rating was 46 [34].

The TIMSS (Trends in International Mathematics and Science Study) exam also assesses the international level of mathematical and science education, such as the PISA exam. This examination is conducted with four year 
intervals. TIMSS; on the 2011 exam, Turkey received 469 math points, which was below the average score of 500 . Turkey was ranked 35 among 57 countries participating. [35]. When these levels of achievement has evaluated, it cannot be denied that changing is necessary for Turkish mathematics education system.

Just like technology, the field of education is influenced by these changes. Student-centered learning environments are created that are the innovative and fully involved in the learning process. Therefore, the use of methods that enable the student to take responsibility for the effective and self-learning environment becomes widespread. Learning logs, known for reflective thinking or learning, are very effective methods for this purpose. According to the literature, there are several studies in different areas in our country to gain reflective thinking or learning and to receive student opinions [27, 25, 6, and 7]. There are also some studies on the use of logs, also seen as a course and teaching process evaluation tool [4, 19, and 26]. This work will contribute to the gap in the field article, especially since the study of daily use in mathematics class is insufficient and no similar work has been observed at the elementary school level. It is a course that is suitable for the development and use of high-level thinking skills such as mathematical course structure and reflective thinking.

When the above mentioned studies and different studies in the field of writing were examined, the diaries were used as an evaluation tool, as a method of improving student's reflective thinking skills, and only as a reference to student's opinions on daily writing. In addition, most of the researches done are directed towards Science and Technology. Rarely, there are researches on Turkish and other courses. The great majority of the samples selected in the studies are seen to be selected from the students who attend university, high school or junior high school. The sample of the study consists of fourth grade students in primary school. In the study, learning logs were used for mathematics lesson. This study contributed to the gap because the work done for daily use in the field writing especially in the mathematics lesson is very inadequate and there is no semi work at the primary school level. Mathematics is an approval course for the development and use of high-level thinking skills such as teaching and reflective thinking. The weight of the abstract topics and topics are considered to be built on top of each other, which is the most appropriate course for continuous evaluation and use of diaries throughout the teaching process.

Aim of present study is evaluating effects of learning logs on academic success at mathematics lesson measuring length topic. In accordance with this purpose, four solutions have been found for these questions below:

1. Is there a significant difference between the post test scores of experimental and control groups?

2. Is there a significant difference between the post test scores of experimental and control groups' boy and girl students?
3. Is there a significant difference between the post test scores of girl and boy students of experimental group?

\subsection{Reflective Thinking}

It is important to determinate how learning information's has obtained in the learning process. Determining learning aim is very substantial and problematic. For mentioning about unsuccessful learning, we have to establish learning aims firstly. Pupils have to be guided all over learning process [1]. Reflective thinking is not a novel approach at education. Theories about the history of reflective thinking extend back to Dewey. Dewey defined reflective thinking as active, permanent and careful think on belief or idea. He has claimed that reflective thinking is basis of learning and understanding [9]. Reflective thinking can be defined as cycle of learning that emanates from professional experiences [32]. Mathematical reflective thinking definition has been developed by Hepsi [16].

In relation to a phenomenological mathematical concept, interpretation capacity refers to the ability to assess the reality of an argument, the ability to demonstrate the similarities of precedents, the ability to analyze, to generalize the questions and answers, and the ability to distinguish related and unrelated data.

\subsection{Importance of Reflective Thinking in Education}

Reflective thinking has very important role at all kinds of daily activities. Individuals use thinking process for realizing any daily activity. Learning practice can be seen as one of these activities. One of the many things that affect the learning process is reflective thinking. It is hard to define reflective thinking. Many of educators define reflective thinking as components that impelling to thinking generally $[3,12]$. Many of educators share a common opinion about centering concepts of making sense to active learning [10]. Reflective teaching is an important part of teacher training programs as an effective teacher is an essential feature [2]. High-level thinking requires the ability to understand, comprehend, synthesize, generalize, and use hypothesis development skills to solve problems related to new situations encountered [29]. In this context, reflective thinking, which is a high level of cognitive skill without thinking, has come to the forefront as the main subject in constructivist understanding. Because reflective thinking, which is an inquiry approach that emphasizes constructivism in teaching, allows for the restructuring of individual experiences [21]. He believes that when students have problems, thinking in a scientific environment systematically, carefully and disciplined will make it easier to solve the problems. Educational theorists have suggested that in all classes students should use reflective thinking and similar high-thinking methods to 
improve their decision-making skills [20]. Reflective teaching helps to reach the goal through natural problem and solve methods by increasing student-teacher interaction and motivation - the quality of teaching. It enables the learner to explore his or her talent and vision, to approach it with different perspectives around it, to converge and diverge. "In the reflective education system, students can set their own learning goals, take responsibility for their own learning, correct their own mistakes, motivate themselves by reaching the distinction of their positive behavior and freely express their views" [28]. Reflective thinking activities during practice are more effective in changing the ideas and stereotypes of individuals [23]. Ünver [28] describes reflective thinking in the process of learning-teaching as a process of thinking about solving positive and negative situations according to the teaching method and level of the teacher and solving the problems. Dewey [9] defines that education is the restructuring of experienced experiences, so that quality changes and this process constitutes the process of reflective thinking. It is also considered necessary to keep a mirror in the process of passing through to ensure the effectiveness of learning [9]. With reflective thinking, it is necessary for the teacher and the student to think about what they actually do while doing something and to reassess the work they are doing. Thus, students can be conscious and active in the learning process by questioning what they will learn during the lesson. The teacher, after the lesson, carefully observes what he or she has done. In the reflective education system, students can set their own learning goals, take responsibility for their own learning, correct their own mistakes, guide themselves to the distinction of their positive behavior and freely express their views [28]. It appears that both the teachers and the teachers are involved in activities to utilize and develop reflective thinking skills in the curriculum that was put into effect in the 2005-2006 school years in our country [8].

A curriculum to develop reflective thinking skills for students to develop reflective thinking skills, teachers who can reflect on what they do and teachers that can be an example to them, course contents that support reflective thinking skills in students, and evaluation methods and tools that reveal the development of students in a multi-perspective. For the purpose of learning, what learners should learn is the purpose of formal learning.
Throughout the learning process, the student must develop his/her learning goals and motivation as well as formal learning objectives. Students who combine learning objectives with their own goals progress to a more effective learning process. Proper learning can lead to students that only with capacity revealing its own aims and tools [1]. These tools are reflective thinking tools. "Reflective writing, videotapes, thinking with high voice, group discussions, reflective dialogues, reflective diaries are some of the tools used in the reflective teaching environment" [18].

\subsection{Learning Logs}

"Learning logs are articles where students write their opinions about the learning process and are given periodic supervision by the teachers."[15] It is useful for many educators to take note by pupils. Logs are tools that provide information to teachers about topics that are learned, challenging and problems about learning field. "Some of the learning logs enable students to write their own thoughts and experiences, and reveals the ideas and concepts they gain as a result." [17] "Learning logs contain different applications besides their standard usage. These practices are mostly seen in psychology". [22]

\section{Materials and Methods}

\subsection{Model of Research}

In this study, the effect of learning diaries on measuring lengths of elementary 4th grade mathematics course was examined. For this purpose, pre-test and post-test control group models were used for the experimental models. We have studied with two groups of students, one of which was randomly selected as the control group. Pre-test and post-test were applied to determine any difference after the study, and learning logs were applied to the experiment group. The experimental design of the study is given in Table 1.

Before the investigation was started, the "Length measuring understanding test" was applied as a preliminary test. At the end of the study, the LMUT test was applied again as a post test of both groups.

Table 1. Experimental Design

\begin{tabular}{lccc}
\hline Group & $\begin{array}{c}\text { Length measuring } \\
\text { understanding test }\end{array}$ & $\begin{array}{c}\text { Counter } \\
\text { Operation }\end{array}$ & $\begin{array}{c}\text { Length measuring } \\
\text { understanding test }\end{array}$ \\
\hline $\begin{array}{l}\text { Exp. Group (Randomly } \\
\text { selected) }\end{array}$ & LMUT I & Learning Logs & LMUT II \\
$\begin{array}{l}\text { Control Group (Randomly } \\
\text { Selected) }\end{array}$ & LMUT I & & LMUT II \\
\hline
\end{tabular}




\subsection{Population and Sample}

The research group of the study consists of 35 students, 18 students from 4-A class and 17 students from 4-B class, who continue to primary school in Turhal district of Tokat province in 2014-2015 academic years. By using easy sampling method in the selection of students; experiment and control groups were determined by draw. According to the result of the draw, 4-B class was assigned as experiment group and 4-A class was assigned as control group. Gender distribution of the students in these two classes constituting study group of this research is shown in Table 2 .

Table 2. Working Group

\begin{tabular}{lccccccc}
\hline Group & Class & Girl & \multicolumn{3}{c}{ Boy } & \multicolumn{3}{c}{ Total } \\
& & F & $\%$ & F & $\%$ & f & $\%$ \\
\hline Experiment & $4-B$ & 9 & 52.94 & 8 & 47.06 & 17 & 100 \\
Control & $4-A$ & 9 & 50 & 9 & 50 & 18 & 100 \\
TOTAL & & 18 & 51.43 & 17 & 48.57 & 35 & 100 \\
\hline
\end{tabular}

In order to test the consistency of the groups, pre-test mathematics achievement levels of the experimental and control group students were compared before the research. The results of t-test for the independent groups are given in Table 3 .

Table 3. T-Test Results for Independent Groups on Mathematics Achievement Scores

\begin{tabular}{lcccc}
\hline Group & $\mathrm{N}$ & $\overline{\boldsymbol{X}}$ & $\mathrm{t}$ & $\mathrm{p}$ \\
\hline Experiment & 17 & 59.8 & 1.9 & $.38^{*}$ \\
\hline Control & 18 & 52.7 & & \\
\hline${ }^{\mathrm{p}}<.05$ & & &
\end{tabular}

When Table 3 is examined, it is seen that the difference between the average success scores of experiment and control groups (experiment $=59.8$, control $=52.7$ ) is not statistically significant $(t=1.9, p>.05)$. In the light of this finding, it can be said that there is similarity in terms of success.

\subsection{Data Collection Tools}

In this study, the "Length measuring understanding test (LMUT)" was developed by researchers for the purpose of determining effects on learning "length measuring" topic at 4th grade mathematics course. LMUT has designed as multiple-choice test consisting of four items and a total of 15 questions. Second data collection tool was "Learning Logs". Logs has prepared after meticulously preparation period with literature review.

\subsection{Data Collection and Analysis}

The data collection process lasted eight weeks. In the first week, the LMUT test was applied to both selected classes. During the next six weeks, the length of the measurement was covered in the frame of the mathematics program specified by the Ministry of National Education, and only learning logs were applied to the experimental group. In the last 20 minutes of the mathematics course, the students were given one-to-one correspondence, and the students were provided to fill the journals. After reading the student's diary, it was reiterated that the students have difficulty in conception and the parts where they are missing or misunderstood have been reiterated taking into consideration the suggestions from the students. The students are provided with the necessary feedback on the topic of measuring lengths. In the control group, according to the mathematics curriculum determined by the Ministry of National Education, the topic of measuring lengths was processed but learning logs were not applied. Following the implementation of the sixth learning diary, the LMUT was applied as a posttest to both groups again. The implementation process of learning diaries is shown in Table-4.

Table 4. Implemented Pre-Test, Post Test and Learning Logs Dates

\begin{tabular}{lc}
\hline Implemented Test & Date \\
\hline Pre Test & $09 / 04 / 2015$ \\
Learning $\log -1$ & $16 / 04 / 2015$ \\
Learning $\log -2$ & $21 / 04 / 2015$ \\
Learning log -3 & $27 / 04 / 2015$ \\
Learning log -4 & $04 / 05 / 2015$ \\
Learning log -5 & $11 / 05 / 2015$ \\
Learning $\log -6$ & $18 / 05 / 2015$ \\
Post Test & $25 / 05 / 2015$ \\
\hline
\end{tabular}

\subsection{Validity and Reliability}

While the test items were prepared in order to ensure the validity of the test in our study, five primary school teachers and three primary school mathematics teachers' opinions and recommendations were taken in the field. In the light of these opinions and suggestions, a test was prepared in accordance with the achievements that were determined by Ministry of National Education of the 4th grade mathematics course "Measuring Lengths". The 33 students in the control and experimental group were tested twice at certain intervals. There was no difference in the pre-test and post-test scores of the students who were tested as a result of the deliberations. As a result of comparing pre-test and post-test scores, the KR20 value was found to be .94 . In the pre- and post-test, LMUT was used to conduct multiple-choice questions, item analysis with the Iteman program to check the functionality of the questions. The difficulty levels of the test substances as a result of the analysis of the questions are as shown in Table 5. 
Table 5. Item Analysis

\begin{tabular}{ccc}
\hline Question & Difficulty index $(\mathrm{p})$ & Discrimination index \\
\hline 1 & .66 & .31 \\
2 & .57 & .30 \\
3 & .69 & .35 \\
4 & .52 & .34 \\
5 & .60 & .31 \\
6 & .37 & .30 \\
7 & .54 & .30 \\
8 & .51 & .32 \\
9 & .28 & .31 \\
10 & .37 & .30 \\
11 & .34 & .30 \\
12 & .43 & .34 \\
13 & .31 & .33 \\
14 & .69 & .32 \\
15 & .46 & .31
\end{tabular}

When the table is evaluated, $1,3,5$, and the $14^{\text {th }}$ questions are easy, on $6,9,10,11$, and 13 questions can be evaluated within the scope of the more difficult question and the remaining questions are medium difficulty. It appears that the discriminate index of the prepared test substances is greater than .30 . This shows that there is no problem in applying the value items to the students.

\section{Results}

The first sub-problem of the study was "Is there a significant difference between the post test scores of experimental and control groups?" Kolmogorov-Smirnov test, Levene test and Regression equality test were used to determine whether there was a significant difference between the test scores and the post-test scores after controlling the pre-test scores of the experimental and control groups. For these tests, Kolmogorov-Smirnov test was used to determine whether the groups were normally distributed, Levene test for equality of variances, and Regression equation test for equality of intra-group regression tendencies.

When Table 6 is examined, it is seen that pre-test and post-test scores of both groups show a normal distribution because the $\mathrm{Z}$ values of the pretest and post-test groups are $p>.05$. In order to perform covariance analysis in the research, it is necessary to test the homogeneity of the variances that should be between the scores of the groups. For this purpose, Levene test was applied and the results were obtained. According to the test results, $\mathrm{F}$ value was 2.59; $\mathrm{p}$ value was obtained as .22. Since these values are larger than .05 , it can be said that the assumption of homogeneity of variances is provided. According to the results of the regression equation in the study, $F$ value was found to be 2.10 and $p$ value was found to be .18 . These values were also found to be statistically insignificant as they were greater than $p>.05$ significance level. The result obtained here is that the tendency is the similar for the two groups. After these studies, it was determined that the groups were normal and homogeneous and covariance analysis was performed in this direction. The analysis results are given in Table 7 as descriptive.

When Table 7 is examined, it is seen that pre-test scores (experiment $=9.58, \mathrm{ss}=4.28$ ) of the experimental group, post-test scores (experiment $=12.58$, ss $=6.82$ ). The pre-test scores of the control group are (control $=8.79$, ss =3.56) $($ control $=14.87, \mathrm{ss}=5.89)$. Pre-tests were taken under control and covariance analysis was conducted to determine whether the difference between groups' post test scores was significant. The covariance analysis result is given in Table 8 .

Table 6. Normal Distribution Elasticity Test, Variance Equality Test and Regression Equation Test Results

\begin{tabular}{|c|c|c|c|c|c|c|c|}
\hline \multirow[t]{2}{*}{ Group } & \multirow[t]{2}{*}{ Tests } & \multicolumn{2}{|c|}{ Kolmogorov-Smirnov Test } & \multicolumn{2}{|c|}{ Levene Test } & \multicolumn{2}{|c|}{ Regression of groups Equality Test } \\
\hline & & $\mathrm{Z}$ & $\mathrm{P}$ & $\mathrm{F}$ & $\mathrm{p}$ & $\mathrm{F}$ & $\mathrm{p}$ \\
\hline \multirow[t]{2}{*}{ Experiment } & Pre Test & 1.24 & .25 & & & & \\
\hline & Post Test & .85 & .55 & 2.59 & .22 & 2.10 & .18 \\
\hline \multirow[t]{2}{*}{ Control } & Pre Test & .65 & .98 & & & & \\
\hline & Post Test & .75 & .89 & & & & \\
\hline
\end{tabular}

$* \mathrm{p}<.05$

Table 7. Descriptive Statistics Results According to Preliminary Test and Post Test

\begin{tabular}{lccccc}
\hline Group & $\mathrm{N}$ & Pretest & \multicolumn{3}{c}{ Posttest } \\
& & $\overline{\boldsymbol{X}}$ & $\mathrm{SS}$ & $\overline{\boldsymbol{X}}$ & $\mathrm{SS}$ \\
\hline Experiment & 17 & 9.58 & 4.28 & 12.58 & 6.82 \\
Control & 16 & 8.79 & 3.56 & 14.87 & 5.89 \\
\hline
\end{tabular}


Table 8. Covariance Analysis Results of Pre-Test and Post Test Scores of Experimental and Control Groups

\begin{tabular}{lccccc}
\hline Group & Sum of squares & df & Mean square & F & P \\
\hline Group & 825.96 & 1 & 825.96 & 5.98 & $.01 *$ \\
Error & 9985.87 & 74 & 143.65 & & \\
\hline${ }^{*} \mathrm{p}<.05$ & & & & &
\end{tabular}

When Table 8 is examined, it is seen that $(\mathrm{F}=5.98$ and $\mathrm{p}$ $=.01)$. There is a difference between the pre-test scores and the post-test scores of the experimental and control groups in favor of the experimental group, because the $\mathrm{p}$ value $(\mathrm{p}$ $<.05)$ that determines the level of significance is. Based on the findings, it can be said that mathematics course supported by learning logs has increased students' achievement levels.

As the second sub-problem of the study, "Is there a significant difference between the post test scores of experimental and control groups' boy and girl students?" for the solution of the second sub-problem, covariance analysis was used to determine whether there was a significant difference between pre-test total scores and post-test total scores of boy students in experimental and control groups. Descriptive statistical results of pre-test and post-test scores of boy students in experimental and control groups are given in Table 9.

Table 9. Descriptive Statistical Results of Pre-test and Post Test Scores of Boy Students in Experimental and Control Groups

\begin{tabular}{lccccc}
\hline Group & N & Pretest $\overline{\boldsymbol{X}}$ & SS & Posttest $\overline{\boldsymbol{X}}$ & $\mathrm{SS}$ \\
\hline Experiment (Boys) & 8 & 8.54 & 8.54 & 16.78 & 1.56 \\
Control (Boys) & 9 & 9.98 & 5.25 & 15.78 & 1.24 \\
Experiment (Girls) & 9 & 12.52 & 5.98 & 51.78 & 1.68 \\
Control (Girls) & 9 & 9.89 & 4.58 & 32.58 & 1.45 \\
\hline
\end{tabular}

When Table 9 is examined, it is seen that the pre-test scores (experiment $=8.54$, ss $=8.54$ ) of the boy students in the experimental group and post-test post-test scores (experiment $=16.78$ ss $=1.56)$ are seen. The pre-test scores of the boy students in the control group were (control $=9.98 \mathrm{ss}=5.25)$ while the post test scores (control $=15.78$, ss $=1.24)$. And also it is seen that pre-test scores (experiment $=12.52$ ss $=5.98$ ) and post-test post-test scores (experiment $=51.78 \mathrm{ss}=1.68$ ) are observed for the girls in the experimental group. The pre-test scores of the students in the control group were (control $=9.89 \mathrm{ss}=4.58)$ and post test scores (control $=$ 32.58 , ss $=1.45$ ). The covariance analysis results obtained by controlling the pre-tests in order to determine whether the difference between the post-test scores of the boy and girl students in the experimental and control groups is significant is given in Table 10 .
Table 10. Results of Covariance Analysis of Post Test Scores when Pre-Test Scores are controlled by Boy Students in the Control and Experiment Group

\begin{tabular}{lccccc}
\hline Group & Sum of squares & df & Mean square & $\mathrm{F}$ & $\mathrm{P}$ \\
\hline Group (Boys) & 450.78 & 1 & 450.78 & 5.98 & $.03^{*}$ \\
Error (Boys) & 2270.36 & 29 & 78.396 & & \\
Group (Girls) & 589.78 & 1 & 589.78 & 4.35 & $.03 *$ \\
Error (Girls) & 5578.65 & 41 & 135.98 & & \\
\hline$* \mathrm{p}<.05$ & & & & &
\end{tabular}

When Table 10 is examined, it is understood that the difference between the test scores of boy students in the groups is statistically significant since $F=5.98$ and $p$ $<0.05$. There was a significant difference in the post test scores of the boy students in the experimental and control groups in favor of the experimental group. Learning logs can be said to be academically more successful in measuring lengths by being influenced positively by the learning groups of boy students in the experimental group.

The scores calculated to analyze the significance of the difference between post-test scores of girl students in the experimental and control groups $(\mathrm{F}=4.35, \mathrm{p}=.03)$. $(\mathrm{F}=$ $4.35, \mathrm{p}<0.05)$, it is understood that the difference between the test scores of the girl students in the groups is statistically significant. There was a significant difference in the post test scores of the girl students in the experimental and control groups in favor of the experimental group. Learning logs can be said to be academically more successful in measuring lengths by being affected positively by the students' learning diaries in the experimental group.

The third sub-problem of the study was stated as "Is there a significant difference between the post test scores of girl and boy students of experimental group?" for the solution of the fourth sub-problem, $t$ test was applied in unrelated groups. The t-test results in unrelated groups are shown in Table 11 to determine whether there is a significant difference between the posttest total scores of the experimental group girls and boys.

Table 11. Gender Based t-Test Results

\begin{tabular}{lccccc}
\hline Gender & $\mathrm{N}$ & $\overline{\mathbf{X}}$ & $\mathrm{Ss}$ & $\mathrm{t}$ & $\mathrm{p}$ \\
\hline Girl & 9 & 51.78 & 16.80 & 2.25 & $.03^{*}$ \\
Boy & 8 & 16.78 & 12.40 & & \\
\hline$* \mathrm{p}<.05$ & & & & &
\end{tabular}


When Table 11 is examined, it is seen that the mean scores of girl students in the experimental group (girl $=$ $51.78 \mathrm{ss}=16.80)($ boy $=16.78 \mathrm{ss}=12.40)$ of the boy students in the experimental group. The gender-based $\mathrm{t}$-score was $(\mathrm{t}=2.25, \mathrm{p}=.03) .(\mathrm{t}=2.25, \mathrm{p}<.05)$, the difference between the averages of boy and girl students is statistically significant and this difference seems to be in favor of girl students.

\section{Conclusions and Discussion}

The first sub-problem of the study was "Is there a significant difference between the post test scores of experimental and control groups?" It was determined that there was a significant difference between the posttest total scores in favor of the experimental group when the preliminary test scores were controlled by analyzing the data as a result of the research conducted. This result shows that learning diaries are successful in the students' conceptions of length.

Through the learning logs, students reflect on the thinking about length, where they make mistakes and where they learn wrongly. As the teacher reads the learning diaries and gives feedback, the teacher sees how things should be done by seeing what the learners do not understand.

According to Arter et al.'s [5] study, learners can transfer their views, experiences, understandings and learning to their teachers through learning diaries. Teachers can observe the progress of the student by giving feedback about the student through the student's diary. In his work on Wormeli [33] learning logs; learning diaries were a tool for the students to follow their own learning and transfer their thoughts to their teacher. As a result; the use of learning diaries in the education system has made it clear that students will learn the length issue more accurately.

As the second sub-problem in the scope of the research, "Is there a significant difference between the post test scores of experimental and control groups' boy and girl students?" As a result of the analyzes, boy students in the experimental and control groups were found to have a statistically significant difference in the post test total scores in favor of the boy students in the experimental group when the pretest total scores were controlled. According to the results obtained here, boy students in the experimental group seem to have a better understanding of the length issue thanks to their learning logs. And also it was found that there was a statistically significant difference in the post test total scores in favor of the girl students in the experimental group when the pretest total scores were controlled for girl students in experimental and control groups. According to the result obtained here, it is seen that the students in the experimental group have a better understanding of the length issue thanks to their learning logs.
The student who writes the learning diary examines the learning diaries written by him and observes himself during the process. The teacher reviews the written learning logs and shares them with the student [30]. It can be argued that when the gauges obtained after the application of the learning gauges are processed after the measurement of the lengths are examined, it is said that the boys and girls have a good understanding of measuring the lengths and that the learning diary has improved the student's ability to grasp positively.

The third sub-problem of the study was "Is there a significant difference between the post test scores of girl and boy students of experimental group?" As a result of this analysis; the learning diaries applied to the experimental group were found to be more effective in terms of measuring the lengths of girl students than boy students.

In study of Drews [11], it is necessary to explain the thoughts that individuals have in their minds and to receive feedback from their teachers so that learning in mathematics can take place effectively.

In this study, when the diaries applied to the experimental group were examined, it was determined that girl students wrote more detailed texts than boy students. In the study by Waskita [31], it is seen that girl students use language more effectively than boy students in writing. This supports the result of our study.

\section{REFERENCES}

[1] Abdul, M. (2011). The situations that can bring reflective thinking process in mathematics learning. In Proceedings International Seminar and the Fourth National Conference on Mathematics Education. Department of Mathematics Education, Yogyakarta State University.

[2] Afshar, H. S. \& Farahani, M. (2015). Reflective thinking and reflective teaching among Iranian EFL teachers: do gender and teaching experience make a difference?. Procedia-Social and Behavioral Sciences, 192.

[3] Akbari, R. (2007). Reflections on reflection: A critical appraisal of reflective practices in L2 teacher education. System, 35(2).

[4] Arslan, D. \& Ilgın, H. (2011). Türkçe dersinde öğrenci günlüklerinin değerlendirme arac1 olarak kullanılması. Mustafa Kemal Üniversitesi Sosyal Bilimler Enstitüsü Dergisi, 8(16).

[5] Arter, J. A., Chappuis, J., Chappuis, S., Stiggins, R. J. (2007). Classroom assessment for student learning: doing it right - using it well. United State of America: Allyn \& Bacon

[6] Cengiz, C., \& Karataş, F. Ö. (2014). Yansıtıcı düşünmeyi geliştirme: fen bilgisi ögretmen adayları ile gerçekleştirilen yansitıcı günlük tutma uygulamasının etkileri, Eğitim ve Ögretim Araştırmaları Degisi, 3(4) 
[7] Çavuş, E. \& Özden, M. (2012). İlköğretim öğrencilerinin fen ve teknoloji dersinde fen günlüğü kullanımına ilişkin görüşleri. Adiyaman Üniversitesi Fen Bilimleri Dergisi, 2(2).

[8] Demiralp, D. (2010). İlköğretim birinci kademe programlarının öğrencilerin yansitıcı düşünmelerini geliştirmeye etkisine yönelik ögrretmen görüşleri (Elazı̆̆ ili örneği).Yayımlanmamış yüksek lisans tezi, Fırat Üniversitesi Sosyal Bilimler Enstitüsü,Elazığ.

[9] Dewey, J. (1933). How we think: A restatement of the reflective thinking to the educative process. Heath.

[10] Doğanay, A. (2007). Üst düzey düşünme becerilerinin ögretimi. Doğanay, A. (Ed.),Ögretim ilke ve yöntemleri. Ankara: Pegem A Yayıncilık.

[11] Drews, D. (2005). Children's mathematical errors and misconceptions: perspectives on the teacher's role. Errors in mathematics: understanding common misconceptions in primary schools. Ed. Allice Hansen, Doreen Drews, John Dudgeon, Fiona Lawton, Liz Surtees. Glasgow: Learning Matters Ltd.

[12] Farrell, T. S. C. (2007). Reflective language teaching: From research to practice. London: Continuum International Publishing Group.

[13] Gökbulut, Y. \& Yumusak, E.Y. (2014). Oyun destekli Matemetik ögretiminin 4. Sınıf kesirler konusundaki erişi ve kalıcılığa etkisi. International Periodical for the Languages Literature and History of Turkish or Turkic. 9/2 Winter, 673-689.

[14] Gülteke, M. (2012). Sinıf ögretmenlerinin matematik özel alan yeterlikleri ile ilgili görüşleri. Yayınlanmamış Yüksek Lisans Tezi, Mehmet Akif Ersoy Üniversitesi. Sosyal Bilimler Enstitüsü, Burdur.

[15] Harmin, M. \& Toth, M. (2006). Inspiring active learning: a complete for handbook for today's teachers. 2. Basım. United States of America: Association Supervision \& Curriculum Development.

[16] Hepsi, N. (2015). Didactic design for improvement phase thinking ability and disposition reflective thinking in mathematics. In Proceeding of International Conference On Research, Implementation And Education Of Mathematics And Sciences 2015 (ICRIEMS 2015), Yogyakarta State University, 17-19 May 2015. Faculty of Mathematics and Sciences Yogyakarta State University.

[17] Hindman, J.L., Stronge, J. H., Tucker, P. D.(2004). Handbook for qualities of effective teachers. Alexandria, VA: Association for Supervision and Curriculum Development. Note: published in Chinese.

[18] Kızılkaya, G., Askar, P. (2009). Problem çözmeye yönelik yansıtıcı düşünme becerisi ölçeğinin geliştirilmesi. Ĕ̌itim ve Bilim, 34(154).

[19] Korkmaz, H. (2004). Fen ve teknoloji eğitiminde alternatif değerlendirme yaklaşımları. Ankara: Yeryüzü Yayınevi.

[20] Kuhn, D. (1990). Developmental perspectives on teaching and learning thinking skills. New York: Jossey-Bass.

[21] Mahnaz, M. (1997). Content and nature of reflective teaching: A case of an experiment middle school science teacher. Clearing House, 70(3).

[22] Rogers, J. (2007). Adults learning. 5. Basim. New York: Open University Press.

[23] Şahin, Ç. (2009).Fen bilgisi öğretmen adaylarının yansıtıcı düşünme yeteneklerine göre günlüklerinin incelenmesi. Hacettepe Üniversitesi Eğitim Fakültesi Dergisi, 36(36).

[24] Şiap, İ. \& Duru, A. (2004). Kesirlerde geometrik modelleri kullanabilme becerisi. Kastamonu Eğitim Dergisi, 12(1), 89-96.

[25] Tok, Ş. (2008). Fen bilgisi dersinde yansıtıcı düşünme etkinliklerinin öğrencilerin akademik başarılarına ve fen bilgisi dersine yönelik tutumlarına etkisi. İlkögrretim Online, $7(3)$.

[26] Toptaş, V. (2011). Sınıf öğretmenlerinin matematik dersinde alternatif ölçme ve değerlendirme yöntemlerinin kullanımı ile ilgili algıları. Eğitim ve Bilim, 36(159), 205-21

[27] Töman, U. \& Çimer, S. O. (2014). Fen bilgisi öğretmen adayları günlüklerinin yansıtıcı düşünme yeteneklerine göre incelenmesİ. Journal of Computer and Education Research, 2(4).

[28] Ünver, G. (2003). Yansıtıcı düşünme. Ankara: PegemA Yayıncilik.

[29] Üstünoğlu, E. (2006). Üst düzey düşünme becerilerini geliştirmede bilişsel soruların rolü. Çă̆daş Eğitim Dergisi, 331 .

[30] Walker, B. J. (2003). Supporting struggling readers. Canada: Pippin Publishing Cooporation.

[31] Waskita, D. (2008). Differences in men's and women's ESL academic writing at the University of Melbourne. Jurnal Sosioteknologi. c. 14. s. 7, 448-463

[32] Wellington, B. (1991). The Promise of Reflective Practice. Educational Leadership, 48(6).

[33] Wormeli, R. (2004). Summarization in any subject: 50 techniques to improve student learning. United States of America: Association for Supervision \& Curriculum Development.

[34] http://www.oecd.org/pisa/keyfindings/pisa-2012-results-ov erview.pdf (Erişim Tarihi: 10.07. 2015).

[35] https://nces.ed.gov/TIMSS/results11.asp, (Erişim Tarihi: 10.07.2015)

[36] https://nces.ed.gov/TIMSS/table11_2.asp, (Erişim Tarihi: 10.07.2015) 